\title{
THE ROUND LIGAMENT IN DEVELOPMENTAL HIP DYSPLASIA: ARE ITS MECHANICAL AND HISTOLOGICAL PROPERTIES PRESERVED?
}

\author{
O LIGAMENTO REDONDO NA DISPLASIA DO DESENVOLVIMENTO \\ DO QUADRIL: SUAS PROPRIEDADES MECÂNICAS \\ E HISTOLÓGICAS SÃO PRESERVADAS?
}

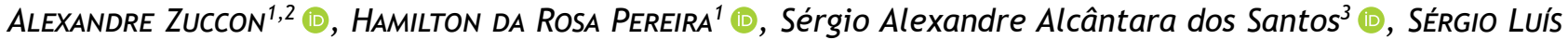

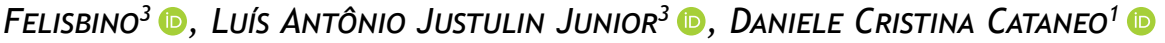 \\ 1. Universidade Estadual Paulista (UNESP), Faculdade de Medicina de Botucatu, Department of Surgery and Orthopedics, Botucatu, SP, Brazil. \\ 2. Associação de Assistência à Criança Deficiente (AACD), Department of Orthopedics, São Paulo, SP, Brazil. \\ 3. Universidade Estadual Paulista (UNESP), Instituto de Biociências de Botucatu, Department of Structural and Functional Biology, Botucatu, SP, Brazil.
}

\section{ABSTRACT}

Introduction: During open surgical dislocated hip reduction, several anatomical structures, such as the round ligament, are approached. However, there is controversy over both the possibility of preserving the ligament and its functional importance. Materials and Methods: This experimental study used skeletally immature rabbits as a model for congenital hip dislocation. Thirty-six rabbits comprised the sample that was submitted to the round ligament analysis. The sample was stratified for analysis (biomechanics, zymography, histology, and immunohistochemistry). Statistical analysis compared the unstable side to the control side of each rabbit. Results: Biomechanical assays showed that the mean maximal strength of the round ligament on the unstable side was similar to that of the control side $(p=0.594)$, which was also the case with maximum deformation $(p=0.328)$. Histologically, there was a statistically significant increase in cellularity on the unstable side $(p<0.001)$. Additionally, there was significantly greater collagen occupancy on the control side ( $p<0.001)$. Zymography revealed no significant difference in the amount of active metalloproteinase $2(\mathrm{MMP}-2)(\mathrm{p}=0.068)$. Conclusions: Although histological analysis found evidence of significant changes in the $R L$ in unstable hips, there were no significant differences in zymography, and no changes were observed in biomechanical tests. Evidence Level V; Experimental study.

Keywords: Collagen. Hip dislocation. Round ligaments. Models, animal. Rabbits.

\section{RESUMO}

Introdução: Durante a redução cirúrgica aberta de luxação de quadril, várias estruturas anatômicas são abordadas, entre elas, o ligamento redondo. No entanto, há controvérsias quanto à possibilidade de preservação desse ligamento, bem como sua importância funcional. Materiais e Métodos: Este estudo experimental usou coelhos esqueleticamente imaturos como modelo de luxação congênita do quadril. Trinta e seis coelhos compuseram a amostra que foi submetida à análise do ligamento redondo. A amostra foi estratificada para análise (biomecânica, zimografia, histologia e imuno-histoquímica). A análise estatística comparou o lado instável com o lado controle de cada coelho. Resultados: Os ensaios biomecânicos mostraram que a força máxima média do ligamento redondo no lado instável era semelhante ao lado controle $(p=0,594)$, o que também ocorreu com a deformação máxima ( $p=0,328)$. Em termos histológicos, houve um aumento estatisticamente significante da celularidade no lado instável $(p<0,001)$. Além disso, houve maior ocupação de colágeno no lado controle $(\rho<0,001)$. A zimografia não mostrou diferença significativa da quantidade de metaloproteinase 2 ativa (MMP-2) ( $p=0,068)$. Conclusões: Embora a análise histológica tenha encontrado evidências de alterações significativas do LR nos quadris instáveis, não houve diferenças significativas na zimografia e não foram observadas alterações nos testes biomecânicos. Nível de evidência V; Estudo experimental.

Descritores: Colágeno. Luxação do quadril. Ligamentos redondos. Modelos animais. Coelhos.

Citation: Zuccon A, Pereira HR, Santos SAA, Felisbino SL, Junior LAJ, Cataneo DC. The round ligament in developmental hip dysplasia: are its mechanical and histological properties preserved? Acta Ortop Bras. [online]. 2022;30(1): Page 1 of 6. Available from URL: http://www.scielo.br/aob.

\section{INTRODUCTION}

Nontraumatic instability of the hip in children may be related to several pathological conditions, and developmental dysplasia of the hip $(\mathrm{DDH})$ is one of the main causes. ${ }^{1}$
When surgical treatment is performed through an open reduction, several structures are approached, including the round ligament $(R L)$. The $R L$ is thickened, and since it is considered a factor that may hinder hip reduction, it is traditionally removed. ${ }^{2,3}$

All authors declare no potential conflict of interest related to this article.

The study was conducted at Faculdade de Medicina de Botucatu - UNESP, Botucatu, SP, Brazil.

Correspondence: Atul K.Taneja. Hospital do Coração (HCor). Rua Des. Eliseu Guilherme, 69, 7. Andar. São Paulo, SP, Brazil. 04004-030. tanejamsk@gmail.com 
Wenger et al. (2008), Bache et al. (2008) and more recently, Youssef (2017) reported their results preserving the RL on DDH surgical correction through an open reduction. In these studies, the authors emphasize how maintaining the round ligament can contribute to hip stability after surgery. ${ }^{4-6}$

Although the $R L$ is a structure that has already been investigated in other studies, there is no clear definition of its histological and biomechanical properties in a dislocated hip. In such cases, it would be worthwhile to know if RL structure and biomechanical function undergo relevant changes that might compromise its preservation in the surgical correction of hip dislocation.

Our hypothesis is that if there are relevant histological and biochemical changes in the RL of dislocated hips, then biomechanical involvement would also occur and compromise $\mathrm{RL}$ function.

\section{METHODS}

This experimental study involved 88 rabbits at 35 days of life (Norfolk breed). An experimental model of $\mathrm{DDH}^{7-8}$ was used in which knee stabilization was performed with one $1.5 \mathrm{~mm}$ Kirschner wire (KW) in one of the hind limbs with the knee in extension (Figure 1). The ipsilateral hip of the limb with the fixed knee was subjected to postural changes and to muscular imbalance that generated articular instability (Figure 2). The contralateral hip served as a control, so each rabbit evaluated with an unstable hip served as its own control.

The experimental protocol was performed according to the Guide to Procedures and Use of Laboratory Animals published by the U.S. National Institute of Health and approved by the institution's Ethics Committee on Animal Use (CEUA) (protocol number: 1012/2013). The animals underwent general anesthesia using $30 \mathrm{mg} / \mathrm{kg}$ ketamine, $5 \mathrm{mg} / \mathrm{kg}$ xylazine, and $5 \mathrm{mg} / \mathrm{kg}$ acepromazine intramuscular infusions. Antibiotic prophylaxis was administered subcutaneously

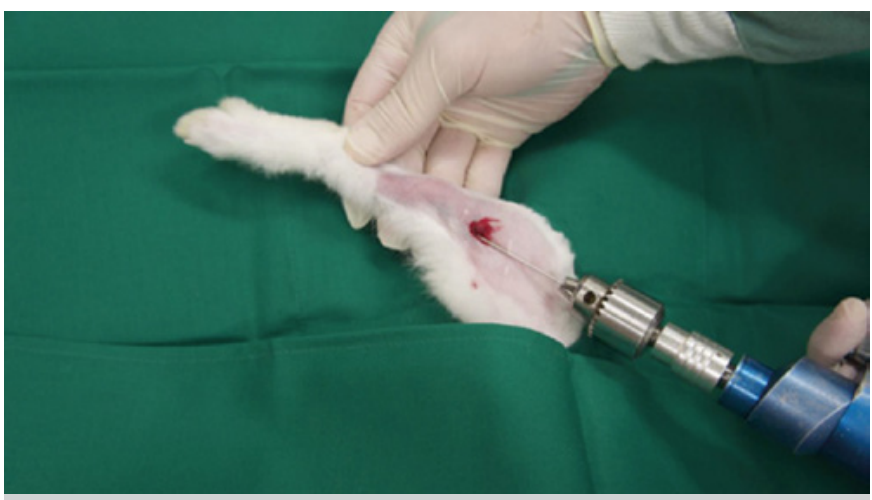

Figure 1. Stabilization with K-wire of the rabbit's knee in complete extension.

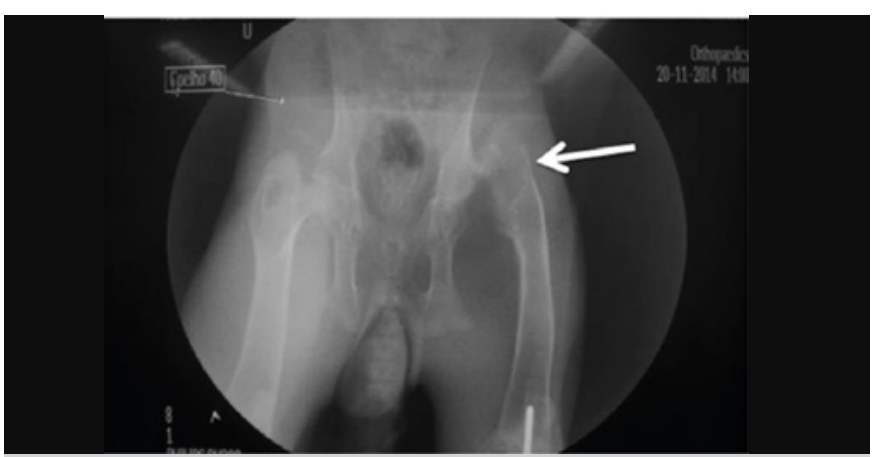

Figure 2. Radiographic image demonstrating left hip dislocation (white arrow) after 6 weeks of ipsilateral knee stabilization. by infusion of enrofloxacin $10 \mathrm{mg} / \mathrm{kg}$ during the anesthetic act. After 24 hours, a new infusion was performed. Analgesia was performed by subcutaneous infusion of tramadol $5 \mathrm{mg} / \mathrm{kg}$ during surgery and every 12 hours for the 3 days following surgery.

Six weeks after the knee fixation, the rabbits underwent euthanasia and radiographic examination was performed to identify unstable hips. Rabbits that did not present with at least $50 \%$ subluxation (defined by the lateral migration of the femoral head ${ }^{9}$ ) were excluded from the study (Figure 3).

Nineteen rabbits died before 6 weeks, 28 did not present instability (50\% subluxation) and/or developed complications and were excluded. In 5 rabbits with unstable hips, it was not possible to identify the $\mathrm{RL}$ for the analysis, therefore they were also excluded. The final sample was 36 rabbits, as depicted in the following flowchart (Figure 4).

Sample size calculation was performed using the $R L$ length values of the first 11 rabbits available for the evaluations comparing the unstable and control sides. After taking values for ligament length on the unstable side $(\bar{x}=7.51 \mathrm{~mm} ; \sigma=1.12)$ and control side $(\bar{x}=4.29$ $\mathrm{mm}, \sigma=0.76$ ) into account and adopting a statistical error (alpha) of

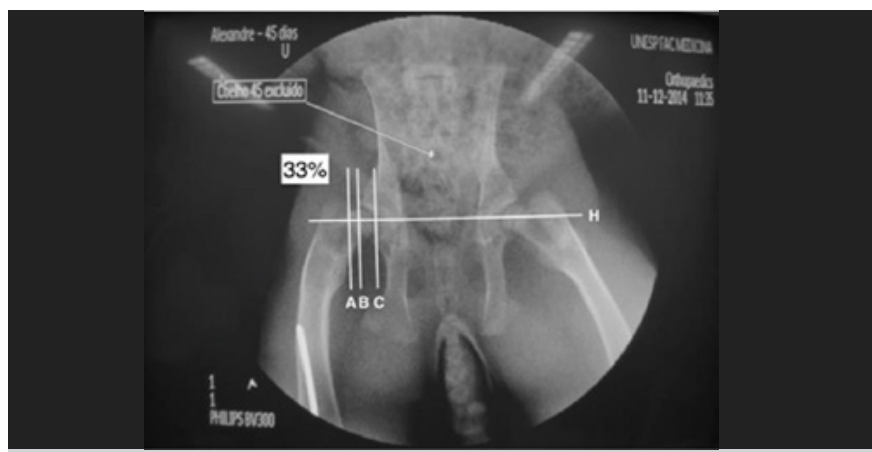

Figure 3. Radiographic image of the right hip presenting $33 \%$ of subluxation (excluded from the study). The $\mathrm{H}$-line passes through the triradiated cartilages of the hips (similar to the Hilgenreiner line), line B is drawn perpendicular to line $\mathrm{H}$ and on the acetabular ridge (similar to the Perkins line), Line $C$ determines the medial limit of the femoral head and line $A$ determines the lateral limit of the same. The percentage of migration was calculated as distance $\mathrm{AB} / \mathrm{AC} \times 100=\%$ of femur head migration (similar to that performed and described by Reimers, 1980).

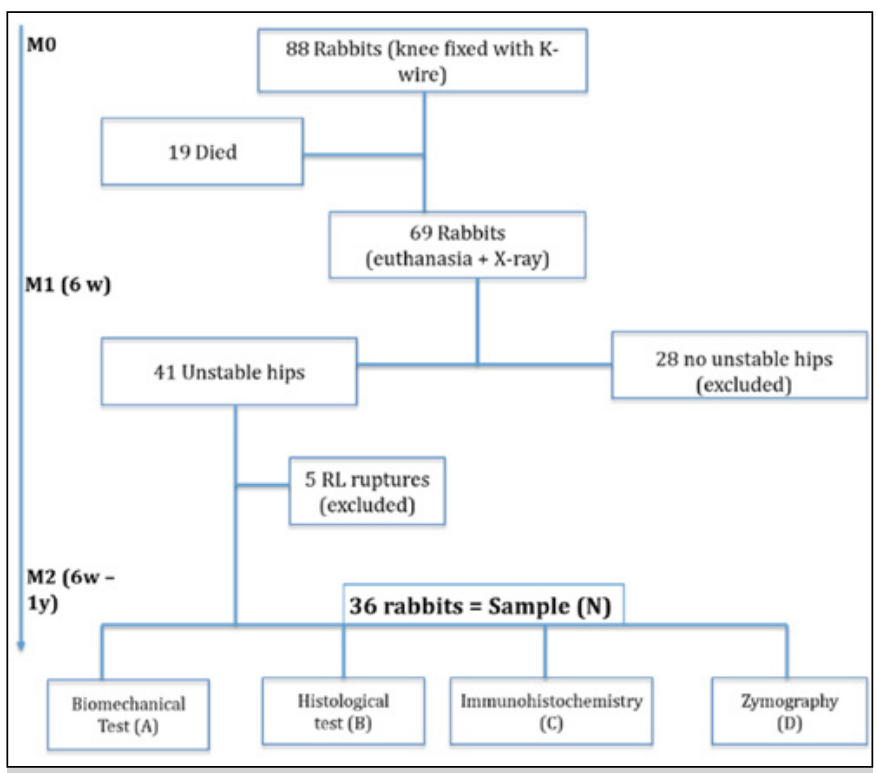

Figure 4. Flowchart of the sample. 
$5.0 \%$, and test power of $80 \%$, the sample was defined as 8 rabbits for each test (e.g., histological, biomechanical and biochemical). The quantitative measures included cellularity and quantification of collagen (histological tests), quantification of metalloproteinases 2 and 9 (zymography), and biomechanical tests. In addition to quantitative measurements, immuno-histochemistry was performed as a qualitative test to identify the presence of fibroblasts.

The sample was analyzed comparing migration percentage and ligament length between sides (control and unstable). The ligament length was not evaluated on rabbits in Group A because it could interfere with the biomechanical test, since some measurements required a small bone resection.

Group randomization was performed to allocate the sample among different quantitative tests.

Twelve rabbits were grouped for biomechanical analysis (Group A) through a load-elongation curve test. Data on maximum strength and maximum deformation were collected from both sides (control and unstable). One rabbit was excluded at this stage because the biomechanical test machine was inadvertently started.

Fourteen rabbits were allocated for histological analysis (Group B). The ligament samples of animals from the different experimental sides $(n=14$ / group $=$ unstable $\times$ control) were prepared and collected on silanized slides stained by hematoxylin-eosin for a general analysis of ligament structure and stained by Picrosirius for automatic detection of collagen fibers. The analyses were carried out in 70 microscopic fields (5 fields per animal of 14 animals / group $=$ unstable $\times$ control) in a Leica ${ }^{\text {}}{ }^{\mathrm{M}}$ DMLB 80 microscope coupled to the digital camera and image analysis software (Leica ${ }^{\text {TM }}$ DC300FX). Cellular (Figure 5) and collagen quantification were completed on both sides.

Group C was composed of 2 rabbits in which an immunohistochemical test was performed in regards to cell specificity (qualitative analysis) through vimentin (Abcam, ab92547, UK) a marker of mesenchymal cells such as fibroblasts.

In Group D, the round ligaments of 8 rabbits of the unstable and control sides were removed and analyzed by zymography for quantification of the metalloproteinases (MMP-2 and MMP-9), as described by Justulin et al. ${ }^{10}$
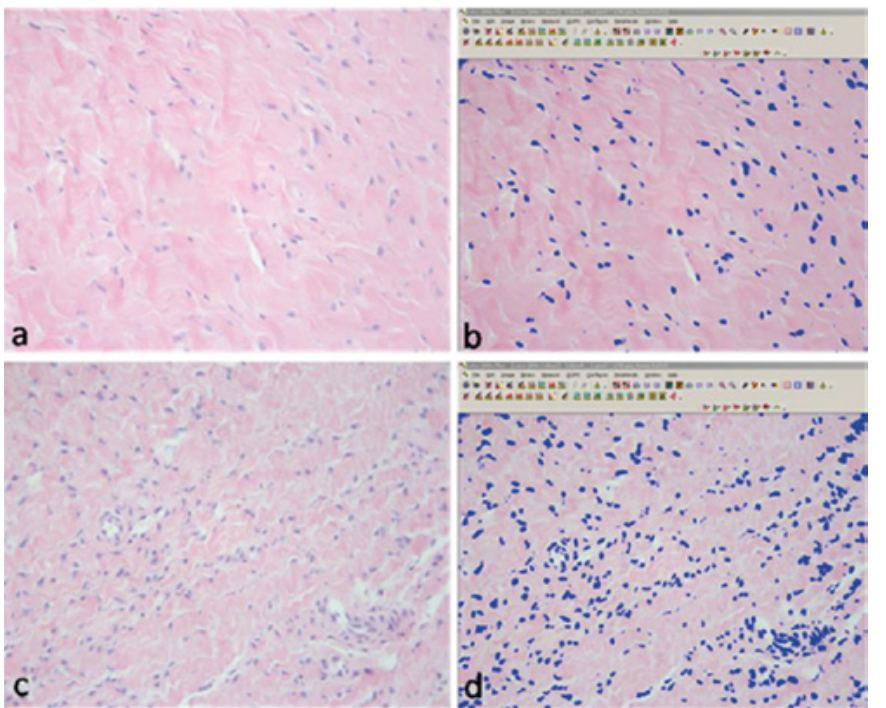

Figure 5. Representative photomicrographs of ligament sections submitted to Hematoxylin and Eosin staining of the control (a) and unstable (c) sides. These images were used for automatic detection of the percentage of area occupied by hematoxylin-stained cell nuclei in control (b) and unstable (d).
Regarding statistical analyses, Wilcoxon tests were performed to evaluate biomechanical tests using a significance level of $5 \%$ and 95\% confidence intervals. For the other analyses, paired Student's t-tests were used, and a significant difference was considered when $p<0.05$. Statistical analyses were performed in the Prisma software (Version 5, GraphPad, Inc., San Diego, CA, USA)

\section{RESULTS}

The mean femoral head lateral migration on the control side was $1.44 \%$ (SD: $3.85 \%$ ) while the mean on the unstable side was $75.19 \%$ (SD:16.6\%). The difference between the evaluated sides was statistically significant $(p<0.001)$ (Table 1).

The mean length of the $R L$ on the unstable side was significantly higher than the mean on the control side $(p<0.001)$ (Figure 6). Forty-six ligaments were used in this comparison (23 rabbits). Only ligament length data from rabbit 72 was not measured.

There was no significant difference between sides (unstable $x$ control) in both the maximal strength of the $R L$ before the rupture $(p=0.594)$, and in the maximum deformation of the ligaments ( $p$ $=0.328$ ) (Figure 7; Tables 2 and 3).

The cellularity was significantly higher on the unstable side with an average of $6.83 \%$ (SD: $3.47 \%$ ) cells per field ( $p<0.001$; Table 4). The control side showed $3.87 \%$ (SD: $2.13 \%$ ).

Immunohistochemistry has shown that the cells verified in histological tests were consistent with fibroblasts.

The amount of collagen was higher on the control side with $84.5 \%$ (SD: $9.5 \%$ ) of occupancy detection, while on the unstable side there was $74.3 \%$ (SD: 10.5\%) $(p<0.001)$

On zymography, there was no MMP-9 activity identified on either side. MMP-2 (active form) appeared to be more active on the unstable side, but the difference was not statistically significant $(p=0.068)$ (Table 5).

\section{DISCUSSION}

The RL has been studied since the 19th century, and its structure and functionality have long been a source of controversy.11

Table 1. Comparison between control and unstable sides for the percentage of femoral head migration seen on radiographs.

\begin{tabular}{c|c|c}
\hline Percentage & Control & Unstable \\
\hline Average & $1,44 \%$ & $75,19 \%$ \\
\hline Median & $0 \%$ & $72,50 \%$ \\
\hline SD $^{*}$ & 3,85 & 16,6 \\
\hline Min & $0 \%$ & $50 \%$ \\
\hline Max¥ & $15 \%$ & $100 \%$ \\
\hline $\mathrm{N}^{\star *}$ & 36 & 36 \\
\hline P-value & \multicolumn{2}{|c}{$<0,001$} \\
\hline${ }^{*}$ Standard Deviation. †inimum value. $¥$ Maximum value. ** Sample (number of rabbits).
\end{tabular}

* Standard Deviation. † Minimum value. $¥$ Maximum value. ${ }^{* \star}$ Sample (number of rabbits).

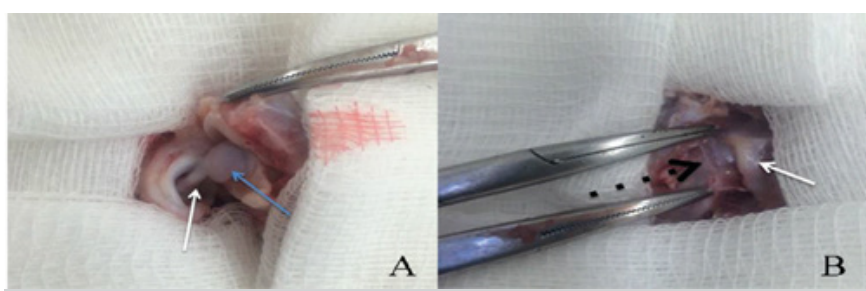

Figure 6. A) Picture of the dislocated hip. The head of the femur (blue arrow) outside the acetabular cavity and thickened elongated ligament (white arrow). B) Picture of the contralateral hip (control) of the same rabbit. Note the head of the femur (dotted black arrow) centered in the acetabulum (white arrow). The ligament on the unstable side was significantly higher. 


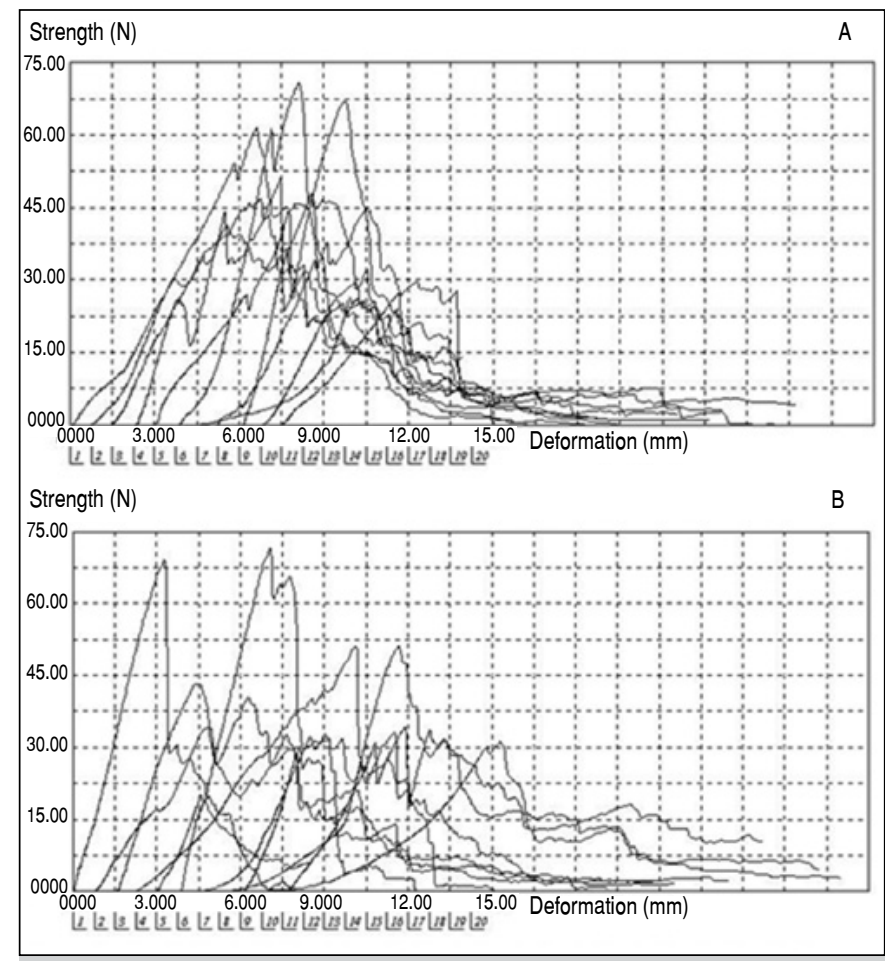

Figure 7. Chart of the biomechanical test showing "strength $x$ deformation" curve on the control side (A) and unstable side (B). Strength was measured in Newtons $(\mathrm{N})$, and deformation was measured in millimeters $(\mathrm{mm})$.

Table 2. Comparison between control and unstable sides for maximum strength (Smax) in Newtons.

\begin{tabular}{c|c|c}
\hline Strength & Control & Unstable \\
\hline Average & 46.62 & 43.25 \\
\hline Median & 46.85 & 40.6 \\
\hline Standard Deviation & 15.56 & 16.25 \\
\hline $\mathrm{Q}^{*}$ & 35.48 & 32.16 \\
\hline $\mathrm{Q}^{*}$ & 56.36 & 51.16 \\
\hline $\mathrm{N}^{\star *}$ & 11 & 11 \\
\hline P-value & \multicolumn{2}{|c}{0.594} \\
\hline${ }^{*}$ |nterquartle value
\end{tabular}

*Interquartile value. ${ }^{* *}$ number of rabbits

Table 3. Comparison between unstable and control sides for maximum deformation in millimeters $(\mathrm{mm})$.

\begin{tabular}{c|c|c}
\hline Deformation & Control & Unstable \\
\hline Average & 4.558 & 3.943 \\
\hline Median & 4.574 & 3.712 \\
\hline Standard Deviation & 1.194 & 1.888 \\
\hline $\mathrm{Q}^{*}$ & 4.033 & 2.872 \\
\hline $\mathrm{Q}^{*}$ & 4.960 & 4.906 \\
\hline $\mathrm{N}^{\star \star}$ & 11 & 11 \\
\hline $\mathrm{P}$-value & \multicolumn{2}{|c}{0.328} \\
\hline
\end{tabular}

${ }^{*}$ Interquartile value. ${ }^{* *}$ number of rabbits

There are some experimental studies on $\mathrm{RL}$ function in hip stability. Smith et al. (1963) $)^{12}$ compared the hips of dogs that underwent resection of the $\mathrm{RL}$ alone with 2 other groups. One group underwent capsular resection and the other had resection of both the $R L$ and the capsule. The authors reported a higher number of dislocation in the hips among those with the $\mathrm{RL}$ resection, which highlighted the possible importance of the RL in joint stability.

Wenger et al. (2007) ${ }^{13}$ conducted an experimental study of the resistance of the $R \mathrm{~L}$ to maximum tensile strength in pigs. Ultimately,
Table 4. Comparison of cellularity between the Control and Unstable sides through the parameters: mean, median, standard deviation, minimum value (Min), maximum value (Max), number of microscopic fields evaluated $(\mathrm{N})$ and $\mathrm{P}$ value.

\begin{tabular}{c|c|c}
\hline Cellularity & Control & Unstable \\
\hline Average & $3.87 \%$ & $6.83 \%$ \\
\hline Median & $3.46 \%$ & $6.27 \%$ \\
\hline Standard Deviation & $2.13 \%$ & $3.47 \%$ \\
\hline Min & $1.36 \%$ & $1.51 \%$ \\
\hline Max & $11.05 \%$ & $15.32 \%$ \\
\hline $\mathrm{N}$ & 70 & 70 \\
\hline P-value & $<0,001$ &
\end{tabular}

Table 5. The mean values of MMP-2 (intermediate and active forms) were compared between the unstable and control sides using the following parameters in arbitrary units (AU): mean, standard deviation, coefficient of variation (CV), minimum value (Min), maximum value (Max), number of rabbits $(\mathrm{N})$ and $\mathrm{P}$ value.

\begin{tabular}{c|c|c|c|c|c|c|c|c}
\hline \multicolumn{2}{c|}{$\begin{array}{c}\text { Zymography } \\
\text { (per thousand) }\end{array}$} & Mean & $\begin{array}{c}\text { Standard } \\
\text { Deviation }\end{array}$ & CV & Min & Max & N & P-value \\
\hline \multirow{2}{*}{$\begin{array}{c}\text { Intermediate } \\
\text { (MMP-2) }\end{array}$} & Control & 6.453 & 873 & $14 \%$ & 5.155 & 8.069 & 8 & \multirow{2}{*}{0.979} \\
\cline { 2 - 10 } & Unstable & 6.472 & 1.900 & $29 \%$ & 3.102 & 9.088 & 8 & \\
\hline \multirow{2}{*}{ Active (MMP-2) } & Control & 294.4 & 78 & $26 \%$ & 254 & 484 & 8 & \multirow{2}{*}{0.068} \\
\cline { 2 - 9 } & Unstable & 481.8 & 228 & $47 \%$ & 247 & 872 & 8 & \\
\hline
\end{tabular}

it was concluded that the biomechanical behavior of this ligament is similar to the anterior cruciate ligament of the knee. Once again, this highlighted the function of the $R L$ as a hip stabilizer, and the authors went even further by discussing the maintenance of the ligament in surgeries for open reduction of hips with dysplasia in children. Wenger et al. (2008) ${ }^{14}$ published a series of cases involving 21 patients with hip dislocation associated with both DDH and cerebral palsy, myelomeningocele, and congenital deficiency of the femur. They performed open reduction of the dislocation and used an $\mathrm{RL}$ suture to increase the stability of the hips. Afterone year follow-up, they reported no cases of redislocation and concluded that the procedure is safe while acknowledging the need for a longer follow-up. Bache et al. (2008) ${ }^{5}$ studied children with DDH and reported good results in $97 \%$ of the 109 hips that underwent open reduction using a medial approach with $R L$ suture in the transverse ligament. The authors hypothesized that the RL suture added stability to the joint. More recently, Youssef $(2017)^{6}$ assessed medial open reduction of hips with DDH associated with partial resection and suture of the $R L$ in 40 hips of 32 children and found that results were $97.5 \%$ good and excellent. The author pointed out that there were no cases of redislocation and attributed the positive results to the suture of the RL.

Sarban et al. (2007) ${ }^{15}$ studied the morphological characteristics of $\mathrm{RL}$ in cases of DDH and identified mechanoreceptors. This finding suggested a possible role for proprioception and joint stability. Considerations were also made about the possible histological changes that may occur in the ligament as a result of hip instability. Muratli et al. (2004) ${ }^{16}$ did not identify mechanoreceptors when analyzing the $R L$ and joint capsule of patients with $\mathrm{DDH}$ undergoing surgical treatment. These authors did not agree about the possible biomechanical ligament function.

Ligaments are composed of a cellular component and an extracellular matrix. The predominant cell type in ligaments is the fibroblast which is primarily responsible for the production of collagen and is known to respond to biomechanical load changes that tissues 
are subjected to. Collagen fibers are responsible for the structural mechanical strength of the tissue (Goh et al., 2003) ${ }^{17}$.

Collagen degradation is carried out through a family of zinc dependent enzymes known as metalloproteinases (MMPs). The control of metalloproteinase activity is performed by the tissue inhibitors of metalloproteinases (de Melo et al., 2009) ${ }^{18}$.

Considering the possible changes in strength that the $\mathrm{RL}$ of unstable hips are subjected to and the subsequent structural changes that occur in that ligament, this study was designed to examine the biomechanical, histological and biochemistry properties of the RL. Some studies ${ }^{5,14,15}$ have suggested a modification in one of the steps of the surgical correction of dislocated hips in children: the maintenance of the RL. However, there is no evidence to date that the $R L$ in an unstable hip maintains its normal properties.

On the unstable side, a higher number of fibroblasts, higher MMP-2 activity (although not statistically significant) and a lower amount of collagen were observed. From these results, it can be concluded that there must be greater strength acting on the $R L$ on the unstable side that results in greater activity both of collagen production and degradation. This activity is important for RL properties.

In cases of more relevant lesions, there is evidence of greater inflammatory activity in the tissue, which may weaken the ligament, since it changes its histological properties in a consistent way as reported in the study of Provenzano et al. (2005). ${ }^{19}$

In the present study, no significant functional change was observed in the $\mathrm{RL}$ with respect to either maximum strength or maximum deformation. The histological and biochemical alterations noted were probably insufficient to change the functional properties of the $\mathrm{RL}$. However, it is important to note that in 5 hips, round ligaments were not found, probably due to their rupture. It is possible that more consistent metabolic changes occurred in these cases, which impacted the resistance of these ligaments. There are reported cases of $R L$ absence in hips which underwent an open reduction in children with DDH (Li et al., 2015) ${ }^{20}$. In this study, the authors identified the severity of the dislocation as a risk factor for the absence of the ligament.

The deformation that occurred in the ligaments during the biomechanical test was not significantly different between sides, but this analysis was performed with absolute values. If it is assumed that the average length of the $R L$ on the unstable side was initially 7.80 $\mathrm{mm}$ (SD: 1.17) and on the control side was $4.08 \mathrm{~mm}(\mathrm{SD}: 0.62)$, a proportionally greater deformation on the control side can be identified. This may indicate a loss of the viscoelastic properties of the unstable hip ligament.

Considering the histological, biochemical and biomechanical characteristics of the round ligaments of the unstable hips, it is recognized that they do not maintain their properties as a normal ligament. However, they appear to retain their tensile strength, since the mean maximum strength did not differ significantly between sides.

Therefore, since its viscoelastic properties are abnormal, if the $R L$ is preserved to aid in hip stabilization in the surgical correction of hip dislocation, the ligament may eventually help to prevent redislocation due to a more primitive biomechanical mechanism that decreases the ligament's capability to improve joint proprioception.

Another important consideration is whether the hip has a more severe dislocation in which case there is higher possibility of more changes in the properties of the $R L$. In addition, the likelihood of $R L$ absence should be remembered in such cases. Therefore, although there are some studies favoring the maintenance of $R \mathrm{~L}$ in the open reduction of dislocated hips in children ${ }^{5,14,15}$, more clinical studies with a better level of evidence need to be conducted.

A limitation of this study is its experimental design, which is a limiting factor when making suggestions for clinical practice. However, since the study is focused on comparing the properties of $R L$ in dislocated and normal hips, it might not be possible to perform the study in any other way.

Another limitation was our inability to proportionately assess changes in deformation in the ligaments following the biomechanical test. Additionally, analyzing ligaments in long-standing dislocations might perhaps add information about the behavior of the ligament in more chronic cases.

Finally, a stratified analysis of the hips of the dislocated group could perhaps provide further information on which ligaments present with the most morphological and functional changes. Due to the small sample size in our study, this analysis was not possible.

\section{CONCLUSION}

Significant histological changes were observed in the RL of unstable hips, but no changes were observed with respect to biochemical and biomechanical tests.

AUTHORS' CONTRIBUTION: Each author contributed individually and significantly to the development of this article. AZ: Conceptualization, formal analysis, Investigation, Methodology, project administration, writing - original draft e writing - review. HRP: conceptualization, supervision, writing - review. SAAS: Methodology, investigation, software. SLF and LAJJ: Resources e methodology. DCC: Supervision, data curation e validation, writing - review.

\section{REFERENCES}

1. Herring JA. Developmental dysplasia of the hip. In: Herring JA, editor. Tachdjian pediatrics orthopaedics. 4thed. Philadelphia: Saunders Elsevier; 2008. p. 637-770.

2. Salter RB. Innominate osteotomy in treatment of congenital dislocation and subluxation of the hip. J Bone Joint Surg Br. 1961;43:518-39.

3. Weinstein SL, Mubarak SJ, Wenger DR. Developmental hip dysplasia and dislocation. Part II. J Bone Joint Surg Am. 2003;85:2024-35.

4. Wenger DR, Mubarak SJ, Henderson PC, Miyanji F. Ligamentum teres maintenance and transfer as a stabilizer in open reduction for pediatric hip dislocation: surgical technique and early clinical results. J Child Orthop. 2008;2:177-85.

5. Bache CE, Graham HK, Dickens DR, Donnan L, Johnson MB, Nattrass G, et al. Ligamentum teres tenodesis in medial approach open reduction for developmental dislocation of the hip. J Pediatr Orthop. 2008;28:607-13.

6. Youssef $A O$. Medial approach open reduction with ligamentum teres partial excision and plication for the management of congenital hip dislocation. $J$ Pediatr Orthop B. 2018;27:244-49.

7. Michelsson JE, Langenskiöld A. Dislocation or subluxation of the hip: regular sequels of immobilization of knee in extension in young rabbits. J Bone Joint Surg Am. 1972;54:1177-86.
8. Greenhill BJ, Hainau B, Ellis RD, el-Sayed RM. Acetabular changes in an experimental modelo of developmental dysplasia of the hip (DDH). J Pedriatr Orthop. 1995; 15:789-93.

9. Reimers J. The stability of the hip in children: a radiological study of the results of muscle surgery in cerebral palsy. Acta Orthop Scand Suppl. 1980;184:1-100

10. Justulin LA Jr, Della-Coleta HH, Taboga SR, et al. Matrix metalloproteinase (MMP)-2 and MMP-9 activity and localization during ventral prostate atrophy and regrowth. Int J Androl. 2010; 33:696-708.

11. O'Donnell JM, Pritchard M, Salas AP, Singh PJ. The ligamentum teres-its increasing importance. J Hip Preserv Surg. 2014;1(1):3-11. Published 2014 Jul 30. doi:10.1093/jhps/hnu003. The ligamentum teres - its increasing importance. J Hip Preserv Surg. 2014;1:3-11.

12. Smith WS, Coleman CR, Olix ML, Slager R. Etiology of congenital dislocation of the hip: an experimental approach to the problem using young dogs. J Bone Joint Surg Am. 1963;45:491-500.

13. Wenger D, Miyanji F, Mahar A, Oka R. The mechanical properties of the ligamentum teres: a pilot study to assess its potential for improving stability in children's hip surgery. J Pediatr Orthop. 2007;27:408-10. 
14. Wenger DR, Mubarak SJ, Henderson PC, Miyanji F. Ligamentum teres maintenance and transfer as a stabilizer in open reduction for pediatric hip dislocation: surgical technique and early clinical results. J Child Orthop. 2008;2:177-85

15. Sarban S, Baba F, Kocabey Y, Cengiz M, Isikan UE. Free nerve endings and morphological features of the ligamentum capitis femoris in developmental dysplasia of the hip. J Pediatr Orthop B. 2007;16:351-56.

16. Muratli HH, Biçimoğlu A, Tabak YA, Celebi L, Paker I. Mechanoreceptor evaluation of hip joint capsule and ligamentum capitis femoris in developmental hip dysplasia: a preliminary study. J Pediatr Orthop B. 2004;13:299-302.
17. Goh JC, Ouyang HW, Teoh SH, Chan CK, Lee EH. Tissue-engineering approach to the repair and regeneration of tendons and ligaments. Tissue Eng. 2003;9:S31-44

18. De Mello Malheiro OC, Giacomini CT, Justulin LA Jr, Delella FK, Dal-Pai-Silva M, Felisbino SL. Calcaneal tendon regions exhibit different MMP-2 activation after vertical jumping and treadmill running. Anat Rec (Hoboken). 2009;292:1656-62.

19. Provenzano PP, Alejandro-Osorio AL, Valhmu WB, Jensen KT, Vanderby R Jr. Intrinsic fibroblast-mediated remodeling of damaged collagenous matrices in vivo. Matrix Biol. 2005;23:543-55.

20. Li T, Zhang M, Wang H, Wang Y. Absence of the ligamentum teres in developmental dysplasia of the hip. J Pediatr Orthop. 2015;35:708-11. 